\title{
Aksi Apoteker Bantul untuk Mendukung Sejawat Tenaga Kesehatan Dalam Penanganan Covid-19
}

\author{
Ingenida Hadning ${ }^{*}$, Muhammad Fariez Kurniawan', Dyani Primasari Sukamdi, Vella Lailli \\ Damarwati', Andy Eko Wibowo', Pinasti Utami', Muhammad Tesa Ghozali, dan \\ Bangunawati Rahajeng1
}

1 Program Studi Farmasi, Fakultas Kedokteran dan Ilmu Kesehatan, Universitas Muhammadiyah Yogyakarta, Jalan Brawijaya, Tamantirto, Kasihan, Bantul, Yogyakarta, 55183

Email: ingenida.hadning@umy.ac.id

DOI: $10.18196 / p p m \cdot 39.125$

\begin{abstract}
Abstrak
Pada masa pendemi Covid-19 saat ini, tenaga kesehatan bertindak sebagai garda terdepan dalam penanganan pasien yang terinfeksi virus Corona. Pengabdian masyarakat ini sebagai bentuk dukungan bagi sejawat tenaga kesehatan yang mengabdi dalam perawatan pasien pada masa pandemi Covid-19. Tenaga kesehatan menjadi pihak yang paling rentan dan berisiko tertular virus Corona dari pasien yang ditanganinya. Hal tersebut menggerakkan sisi kemanusiaan tim pengabdi dari Program Studi Farmasi, FKIK, UMY melaksanakan program pengabdian masyarakat yang berjudul "Aksi Apoteker Bantul untuk Mendukung Sejawat Tenaga Kesehatan dalam Penanganan Covid-19". Tim pengabdi bekerja sama dengan mitra, yaitu organisasi profesi Ikatan Apoteker Indonesia (IAI) Kabupaten Bantul. Tim pengabdi dan mitra bekerja sama dalam pembuatan hand sanitizer dan menyiapkan paket. Tim pengabdi dan mitra juga bekerja sama dalam pendistribusian paket ke empat rumah sakit dan sembilan puskesmas di Kabupaten Bantul. Kegiatan ini dilaksanakan pada tanggal 14-16 April 2020. Dalam kegiatan ini, tim pengabdi dan mitra membagikan 600 paket untuk tenaga kesehatan di Kabupaten Bantul. Paket tersebut berisikan vitamin, madu, susu, dan hand sanitizer yang bertujuan menjaga kesehatan para tenaga kesehatan. Hand sanitizer dibuat sendiri atas kerja sama Program Studi Farmasi, FKIK, UMY dan Program Studi Farmasi, Akbidyo di Laboratorium Riset Program Studi Farmasi, FKIK, UMY. Paket tersebut dibagikan ke empat rumah sakit dan sembilan puskesmas di Kabupaten Bantul. Rumah sakit yang memperoleh paket tersebut adalah RS Panembahan Senopati Bantul, RSPAU dr. S. Hardjolukito, RS PKU Muhammadiyah Bantul, dan RS Santa Elisabeth Bantul. Puskesmas yang memperoleh paket, yaitu Puskesmas Pandak I, Bambanglipuro, Srandakan, Imogiri I, Bantul I, Sedayu I, Banguntapan I, Kasihan I, dan Piyungan. Tim pengabdi berharap pengabdian masyarakat ini membawa manfaat yang besar bagi tenaga kesehatan di Kabupaten Bantul sehingga tenaga kesehatan selalu sehat dan dapat bertugas dengan maksimal dalam merawat pasien Covid-19 pada masa pendemi ini. Diharapkan juga makin banyak masyarakat yang memperhatikan tenaga kesehatan yang berjuang pada masa pendemi ini.
\end{abstract}

Kata Kunci: aksi apoteker, bantul, tenaga kesehatan, pandemi, Covid-19

\section{Pendahuluan}

Pada masa pendemi Covid-19 saat ini, tenaga kesehatan bertindak sebagai garda terdepan dalam penanganan pasien yang terinfeksi virus Corona. Tenaga kesehatan menjadi pihak yang paling rentan dan berisiko tertular virus Corona dari pasien yang ditanganinya (Susilo, et al., 2020; Bavel, et al., 2020; CDCPO, et al., 2020. Hal tersebut menggerakkan sisi kemanusiaan tim pengabdi dari Program Studi Farmasi, FKIK, UMY melaksanakan program pengabdian masyarakat yang berjudul "Aksi Apoteker Bantul untuk Mendukung Sejawat Tenaga Kesehatan dalam Penanganan Covid-19”.

Tim pengabdi bekerja sama dengan mitra, yaitu organisasi profesi Ikatan Apoteker Indonesia (IAI) Kabupaten Bantul. Tim pengabdi dan mitra bekerja sama dalam pembuatan hand sanitizer dan menyiapkan 600 paket yang dapat menunjang kesehatan tenaga kesehatan di Kabupaten Bantul yang langsung menangani pasien Covid-19. Tim pengabdi dan mitra juga bekerja sama dalam pendistribusian paket ke empat rumah sakit dan sembilan puskesmas di Kabupaten Bantul. Pengabdian masyarakat bertujuan memberikan dukungan kepada sejawat tenaga kesehatan yang mengabdi dalam perawatan pasien pada masa pandemi Covid19 melalui pemberian paket penunjang kesehatan.

\section{Metode Pelaksanaan}

Metode pelaksanaan yang digunakan dalam pengabdian masyarakat ini sebagai berikut. 
1. Pembuatan 600 Buah Hand Sanitizer

Pembuatan hand sanitizer dilaksanakan di Laboratorium Penelitian FKIK, UMY pada bulan April 2020 oleh dosen Program Studi Farmasi, FKIK, UMY.

2. Penyiapan 600 Paket Penunjang Kesehatan

Paket penunjnag kesehatan berisi vitamin, madu, susu, dan hand sanitizer. Penyiapan paket dilaksanakan oleh dosen Program Studi Farmasi, FKIK, UMY dan apoteker yang tergabung dalam Organisasi Keprofesian Ikatan Apoteker Indonesia Kabupaten Bantul pada bulan April 2020.

3. Pendistribusian 600 Paket

Pendistribusian paket dilaksanakan pada tanggal 14-16 April 2020. Paket tersebut dibagikan ke empat rumah sakit dan sembilan puskesmas di Kabupaten Bantul. Rumah sakit yang memperoleh paket tersebut adalah RS Panembahan Senopati Bantul, RSPAU dr. S. Hardjolukito, RS PKU Muhammadiyah Bantul, dan RS Santa Elisabeth Bantul. Puskesmas yang memperoleh paket, yaitu Puskesmas Pandak I, Bambanglipuro, Srandakan, Imogiri I, Bantul I, Sedayu I, Banguntapan I, Kasihan I, dan Piyungan.

\section{Hasil dan Pembahasan}

Program pengabdian masyarakat yang berjudul "Aksi Apoteker Bantul untuk Mendukung Sejawat Tenaga Kesehatan dalam Penanganan Covid-19" ini dilaksanakan pada tanggal 14-16 April 2020. Tim pengabdi bekerja sama dengan mitra, yaitu organisasi profesi Ikatan Apoteker Indonesia (IAI) Kabupaten Bantul. Tim pengabdi terdiri atas apt. Ingenida Hadning, M.Sc., apt. Pinasti Utami, M.Sc., apt. M. T. Ghozali, M.Sc., apt. Muhammad Fariez Kurniawan, M.Farm., apt. Dyani Primasari Sukamdi. M.Sc., apt. Vella Lailli Damarwati, M.Farm., apt. Andy Eko Wibowo, M.Sc., dan Dr. apt. Bangunawati Rahajeng, M.Si. yang merupakan staf pengajar di Program Studi Farmasi, FKIK, UMY. Dalam kegiatan ini, tim pengabdi dan mitra membagikan 600 paket untuk tenaga kesehatan di Kabupaten Bantul. Paket tersebut berisikan vitamin, madu, susu, dan hand sanitizer yang bertujuan menjaga kesehatan para tenaga kesehatan.

Kegiatan ini dimulai dengan pembuatan 600 buah hand sanitizer. Pembuatan hand sanitizer tersebut dilaksanakan atas kerja sama Program Studi Farmasi, FKIK, UMY dan Program Studi Farmasi, Akbidyo. Pembuatan hand sanitizer dilaksanakan di Laboratorium Penelitian FKIK UMY. Pembuatan hand sanitizer sendiri didasari pada kelangkaan stok hand sanitizer di Provinsi DIY saat awal pandemi Covid-19 terjadi. Proses pembuatan hand sanitizer dapat dilihat pada Gambar 1 dan produk hand sanitizer dapat dilihat pada Gambar 2.

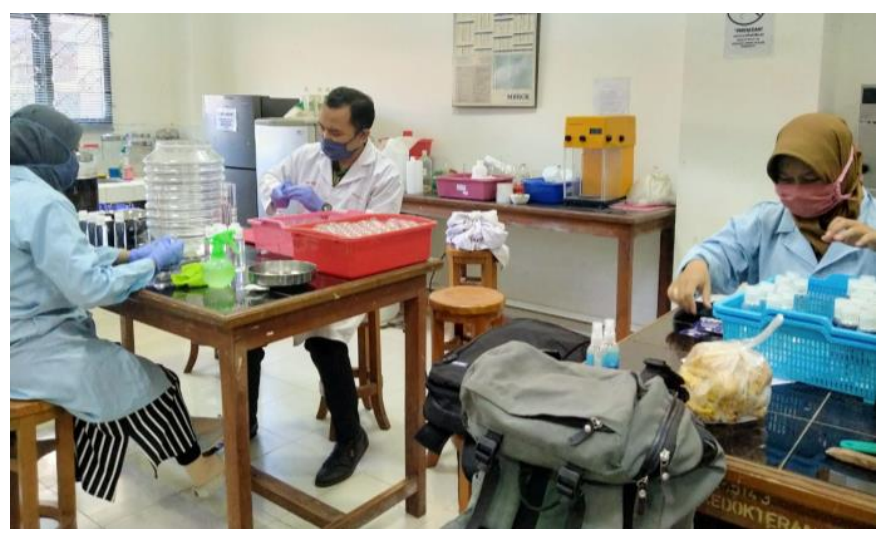

Gambar 1. Proses Pembuatan Hand Sanitizer 


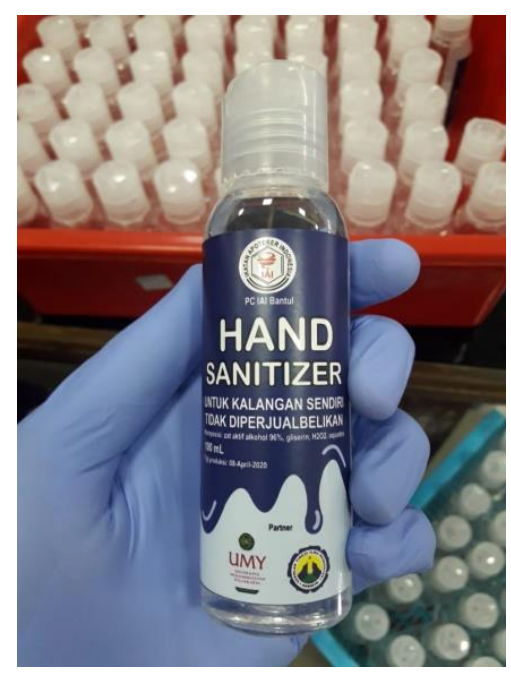

Gambar 2. Produk Hand Sanitizer

Selain hand sanitizer, dalam paket tersebut tim pengabdi dan mitra menyiapkan secara mandiri 600 paket yang terdiri vitamin, madu, dan susu. Paket tersebut bertujuan menjaga kesehatan para tenaga kesehatan. Gambar proses penyiapan paket dapat dilihat pada Gambar 3 dan isi paket dapat dilihat pada Gambar 4.

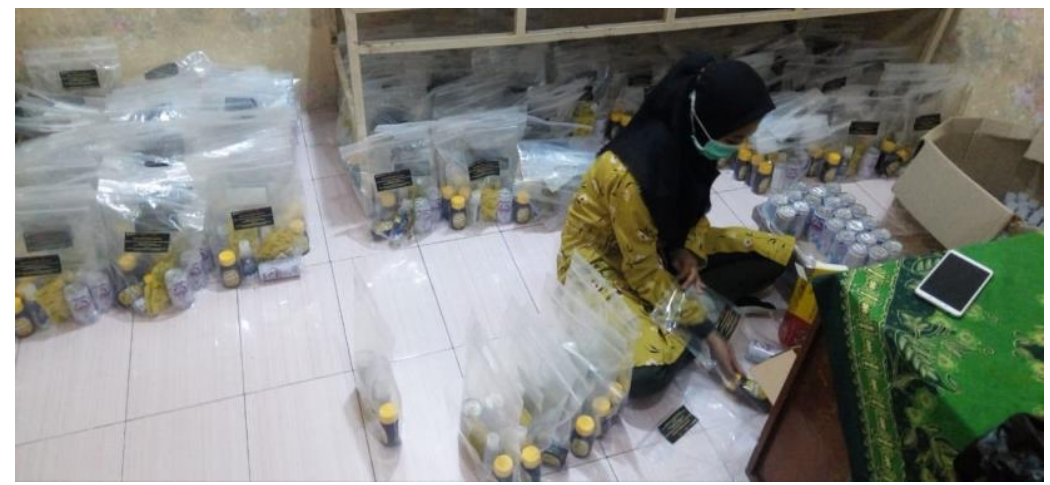

Gambar 3. Proses Penyiapan 600 Paket

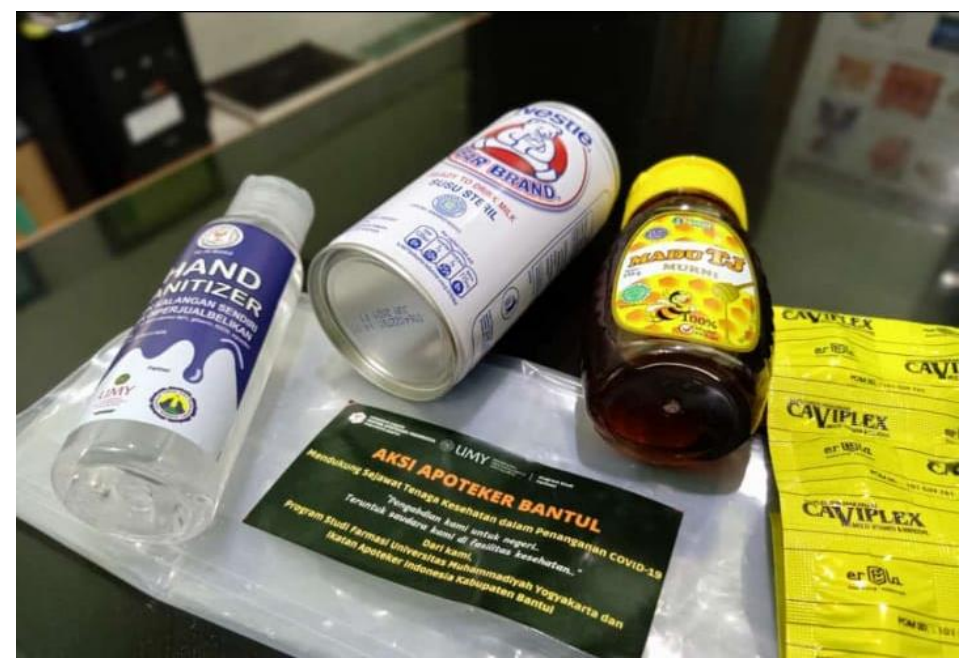

Gambar 4. Isi Paket

Paket tersebut dibagikan ke empat rumah sakit dan sembilan puskesmas di Kabupaten 
Bantul. Rumah sakit yang memperoleh paket tersebut adalah RS Panembahan Senopati Bantul, RSPAU dr. S. Hardjolukito, RS PKU Muhammadiyah Bantul, dan RS Santa Elisabeth Bantul. Puskesmas yang memperoleh paket, yaitu Puskesmas Pandak I, Bambanglipuro, Srandakan, Imogiri I, Bantul I, Sedayu I, Banguntapan I, Kasihan I, dan Piyungan. Proses pendistribusian 600 paket tersebut dapat dilihat pada Gambar 5 dan Gambar 6.

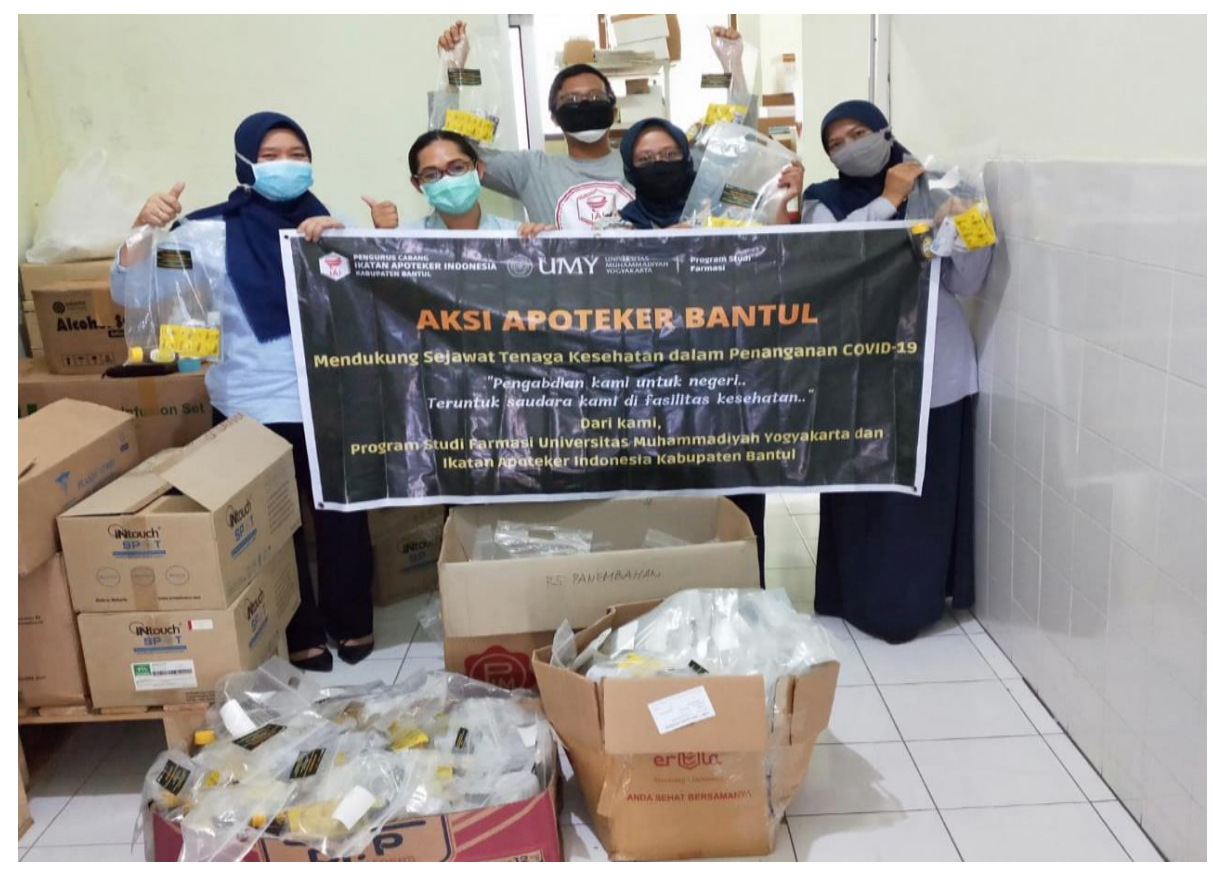

Gambar 5. Pembagian Paket di RS Panembahan Senopati Bantul

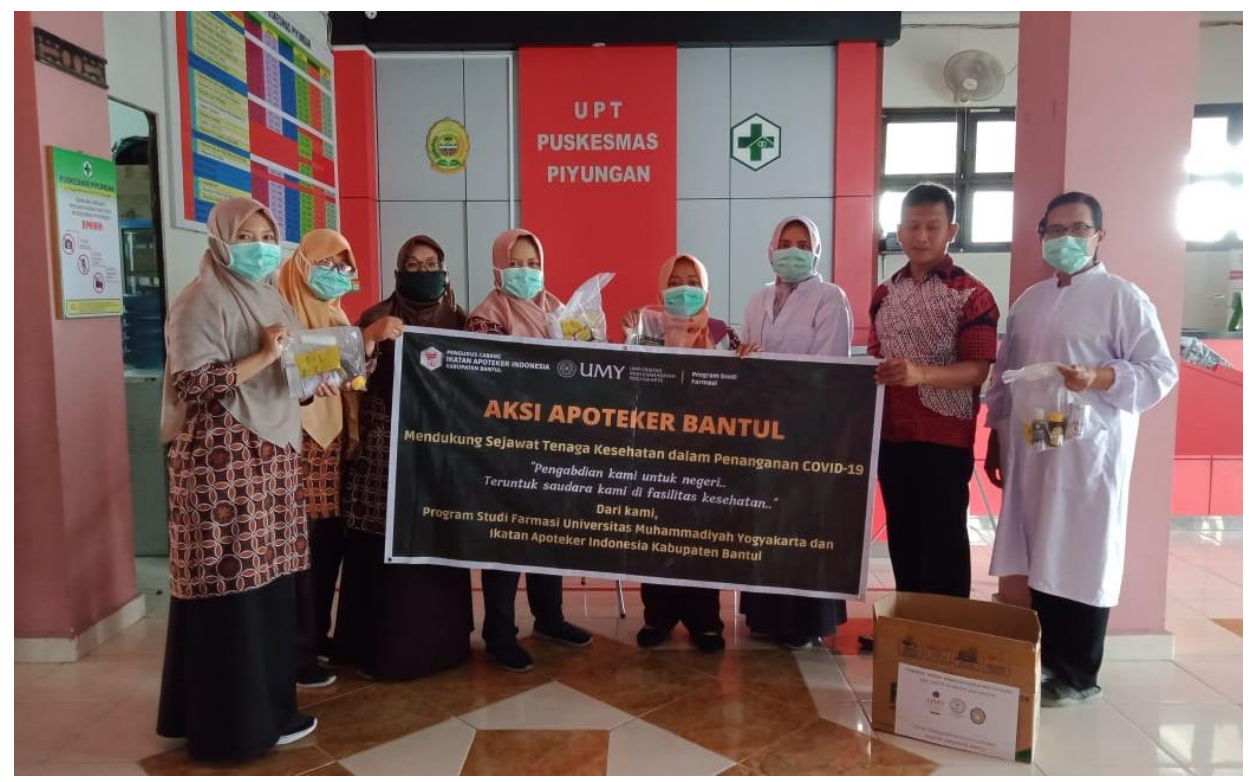

Gambar 6. Pembagian Paket di Puskesmas Piyungan Bantul

Tim pengabdi berharap pengabdian masyarakat ini membawa manfaat yang besar bagi tenaga kesehatan di Kabupaten Bantul sehingga tenaga kesehatan selalu sehat dan dapat bertugas dengan maksimal dalam merawat pasien Covid-19 pada masa pendemi. Selain itu, diharapkan makin banyak masyarakat yang memperhatikan tenaga kesehatan yang berjuang 
pada masa pendemi.

\section{Simpulan}

Pengabdian masyarakat dengan topik "Aksi Apoteker Bantul untuk Mendukung Sejawat Tenaga Kesehatan dalam Penanganan Covid-19" telah terlaksana dengan baik. Paket penunjang kesehatan yang berjumlah 600 paket telah dibagikan ke tenaga kesehatan di empat rumah sakit dan sembilan puskesmas di Kabupaten Bantul.

\section{Ucapan Terima Kasih}

Penulis mengucapkan terima kasih kepada Lembaga Penelitian dan Pengabdian Masyarakat Universitas Muhammadiyah Yogyakarta atas pemberian hibah Pengabdian Kemitraan Masyarakat sehingga kegiatan ini dapat berjalan dengan lancar dan optimal serta bermanfaat untuk mitra kegiatan dan tenaga kesehatan di Kabupaten Bantul. Penulis juga mengucapkan terima kasih kepada mitra pengabdian, yaitu Pengurus Cabang Ikatan Apoteker Indonesia Kabupaten Bantul yang telah mendukung sehingga kegiatan ini dapat berjalan dengan lancar.

\section{Daftar Pustaka}

Susilo, Adityo, et al. (2020). Coronavirus Disease 2019: Tinjauan Literatur Terkini. Jakarta: Fakultas Kedokteran, Universitas Indonesia.

Bavel, et al., (2020): Jay J. Van Bavel, Robb Willer, et al. (2020). Using Social and Behavioural Science to Support Covid-19 Pandemic Response. New York: Standford University.

Centers for Disease Control and Prevention and Other. (2020). Interim US Guidance for Risk Assessment and Public Health Management of Persons with Potential Coronavirus Disease 2019 (Covid-19) Exposures: Geographic Risk and Contacts of Laboratoryconfirmed Cases. https://www.cdc.gov/ coronavirus/ 2019-ncov/php/riskassessment.html diakses pada 23 April 2020. 